\title{
DETECTION OF BOVINE Clostridium perfringens BY POLYMERASE CHAIN REACTION
}

\author{
PIATTI R. M. ${ }^{1}$, IKUNO A. A. ${ }^{1}$, BALDASSI L. ${ }^{1}$ \\ ${ }^{1}$ Centro de Sanidade Animal, Instituto Biológico
}

\begin{abstract}
A polymerase chain reaction (PCR) assay to detect Clostridium perfringens alpha toxin gene (сра) was used to identify eighty-nine $C$. perfringens strains obtained from bovine clinical material. The strains were biochemically characterized as $C$. perfringens. The isolated strains were cultured on plates containing brain heart infusion agar with 5\% sheep blood under anaerobic conditions. DNA extraction was performed by boiling. The 324 bp amplification product of cpa was observed in all isolates. C. sordellii, C. botulinum, C. novyi, and $C$. septicum were also tested but did not produce any alpha toxin gene amplification. These findings suggest that PCR is a useful assay in identifying C. perfringens toxin types.
\end{abstract}

KEY WORDS: Clostridium perfringens, PCR, alpha toxin, polymerase chain reaction.

CORRESPONDENCE TO: R. M. PIATTI - Centro de Sanidade Animal, Instituto Biológico. Avenida Conselheiro Rodrigues Alves, 1252, 04014-002, São Paulo, SP, Brasil. Email: piatti@biologico.sp.gov.br 


\section{INTRODUCTION}

Clostridium perfringens is a widely distributed pathogen known to cause many human and animal diseases. Domestic animals are known to be sources of human food poisoning; to decrease or eliminate this risk, strategies must be developed to prevent infected animals from entering the food chain $(6,10,16)$.

C. perfringens produces a variety of exotoxins; four of these - alpha, beta, epsilon, and iota are considered the major toxins and are used to group the bacteria into five types A, B, C, D, and E. Alpha toxin is produced by all strains and is involved in disease pathogenesis (15).

Organism typing is accomplished by culture filtrates with type-specific antisera; these are difficult to find, extremely expensive, time consuming, and ethically unacceptable for tests in experimental animals $(12,13)$. The use of polymerase chain reaction (PCR) can avoid these problems and may be used to differentiate $C$. perfringens into its five toxin types $(17,20)$.

In this study, 89 C. perfringens isolates that produced animal disease were submitted to PCR assay using primer sets to detect the presence of genes encoding alpha toxin.

\section{MATERIALS AND METHODS}

\section{Strains}

Samples obtained in the post-mortem examination of 144 bovines clinically suspected of having enterotoxaemia were analyzed for the presence of anaerobic microorganisms. This led to the isolation of 89 strains of Clostridium spp, biochemically identified as C. perfringens (1). We also used type A C. perfringens standard strain from the American Type Culture Collection (ATCC), ATCC 3624 as positive control, and C. sordellii, C. botulinum, C. novyi, and $C$. septicum strains to show reaction specificity.

A 3.0 $\mu \mathrm{L}$ aliquot from the positive control and each one of the isolated strains was streaked in a plate containing Brain Heart Infusion (BHI) agar with 5\% sheep blood and incubated under anaerobiosis in McIntosh \& Fields jars at $37^{\circ} \mathrm{C}$ for 18 to 24 hours. 
After incubation, colonies were observed in relation to aspect, color, presence and type of hemolysis, and bacterial morphology, which was microscopically assessed in Gram-stained smears. Five colonies from each plate that were shiny, presented double hemolysis straight edges, and were identified as Gram-positive bacilli; they were collected in physiological saline solution to be analyzed.

\section{Sample preparation}

One to five C. perfringens colonies obtained from BHI blood agar cultures were centrifuged at $13,000 \mathrm{Xg}$ for $5 \mathrm{~min}$, and the pellet was suspended in $50 \mu \mathrm{l}$ of $10 \mathrm{mM}$ Tris- $\mathrm{HCl}, \mathrm{pH} 9.0,50$ $\mathrm{mM} \mathrm{KCl}, 2 \%$ Triton X-100. The mixture was vortexed, boiled for $10 \mathrm{~min}$ for cell lysis, centrifuged at 13,000 X $g$ for $2 \mathrm{~min}$, and $5 \mu \mathrm{l}$ of the supernatant was used as a template.

\section{Polymerase chain reaction - PCR}

Alpha toxin gene (сра) oligonucleotide primers were selected from published sequences (19): 5' GCT AAT GTT ACT GCC GTT GACC 3' and 3' TCT GAT ACA TCG TGT AAG 5'. PCR reactions were performed at a final volume of $50 \mu \mathrm{L}$ with the following reagents: $10 \mathrm{mM}$ Tris-HCl, pH 8.3, $50 \mathrm{mM} \mathrm{KCl,} 50 \mathrm{mM} \mathrm{MgCl}_{2}, 200 \mu \mathrm{M}$ dNTP, 10 pmol of each primer, $2 \mathrm{U}$ Taq DNA polymerase, and $5 \mu \mathrm{l}$ of template DNA. Amplification mixture was incubated in a thermalcycler PTC-200 DNA Engine. Samples were denatured at $95^{\circ} \mathrm{C}$ for 5 minutes and then submitted to 35 cycles of $1 \mathrm{~min}$ at $94^{\circ} \mathrm{C}, 1 \mathrm{~min}$ at $53^{\circ} \mathrm{C}$, and $1 \mathrm{~min}$ at $72^{\circ} \mathrm{C}$, with a further extension cycle of $10 \mathrm{~min}$ at $72^{\circ} \mathrm{C}$. C. perfringens type A ATCC 3624 was used as positive control and water as negative control.

\section{Electrophoresis}

For the detection of the PCR products, $10 \mu \mathrm{L}$ sample of amplified DNA was examined by electrophoresis in $2 \%$ agarose gel with TBE $0.5 \mathrm{X}(0.045 \mathrm{M}$ Tris-borate and 1mM EDTA, pH 8.0) running buffer. Gel was stained with $0.5 \mu \mathrm{g} / \mathrm{mL}$ ethidium bromide. Molecular sizes were determined based on a 100 bp ladder molecular mass marker. The reaction products were analyzed and photographed under UV light. 


\section{PCR specificity}

Total genomic DNA of C. botulinum, C. sordellii, C. septicum, and C. novyi were used in PCR reactions as described above.

\section{RESULTS}

A total of 89 C. perfringens isolates were genotyped using PCR. Figure 1 shows the 324 bpamplified fragment in agarose gel electrophoresis. The gene encoding alpha-toxin (сра) was detected in the reference strain (type A ATCC 3624) and in all isolated field strains. None of the PCR assays using DNA from C. botulinum, C. sordelli, C. septicum, and C. novyi produced this $324 \mathrm{bp}$ fragment, which is uniquely associated with C. perfringens.

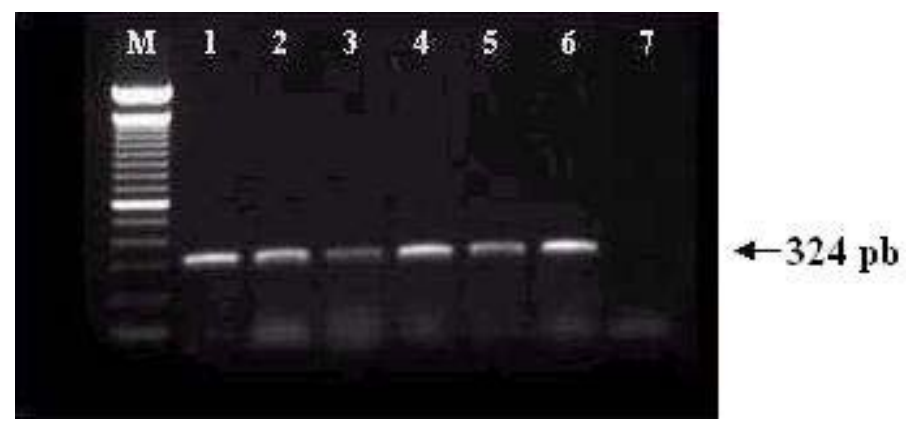

Figure 1. Detection of $C$. perfringens alpha toxin gene amplified by PCR. $M=100$ bp molecular weight marker ladder; 1-5= clinical samples; 6= C. perfringens ATCC 3624 (Type A); $7=$ negative control.

\section{DISCUSSION}

Enterotoxaemia usually occurs in bovine when prophylactic measures are not observed. The presence of $C$. perfringens is also a public health problem since humans can be intoxicated by ingesting contaminated meat. C. perfringens toxin A is a powerful toxin and infection may result in myonecrosis, hemolysis, and increased vascular permeability. The major lethal effects associated with this toxin are gas gangrene in humans and necrotic enteritis and enterotoxaemia in animals $(4,9,14)$. 
It has been identified by seroneutralization in laboratory animals, using specific antisera. This toxin-typing technique requires continuous supply of laboratory animals and use of monovalent diagnostic sera, which are increasingly difficult to find and extremely expensive. Moreover, toxin-typing results are obtained in less than 24 or even 48 h observation $(7,18)$. The use of PCR as a diagnostic assay for detection of toxins producing $C$. perfringens may offer considerable advantage over the above techniques $(3,5,8,11)$.

In this study, alpha toxin gene was found in C. perfringens reference strain type A (ATCC 3624) and in all field isolates tested. No other Clostridium spp gave rise to any amplification of the alpha toxin gene. These results confirm observations made by other authors (2) using PCR amplification to show that alpha toxin gene is specific to $C$. perfringens species. Thus, the alpha toxin gene PCR is suggested as a diagnostic method for confirmation of $C$. perfringens species, providing a good alternative to the time-consuming and specific mouse neutralization test normally used in laboratory routine.

Prophylaxis of enterotoxaemia in animals is achieved by vaccination; PCR technique can thus become a first-choice tool for identification and typing of $C$. perfringens strains that cause disease. In turn, this would simplify the development of vaccines according to epidemiological situation (7).

In this trial, $C$. perfringens field isolates were not random and, therefore, may not accurately represent the distribution of toxin types in animals or disease conditions. However, the predominance of alpha toxin isolates suggests the importance of this agent in animal disease in Brazil. Additional studies must be performed with specific primers to detect other toxins to know the real prevalence of $C$. perfringens types.

\section{REFERENCES}

1 BALDASSI L., CALIL BEM., PORTUGAL MASC., MOULIN AAP., MOURÃO MAF. Morte súbita de caprinos por enterotoxemia. Braz. J. Vet. Res. Anim. Sci., 1995, 32, 109-13. 
2 FACH P., DELBART MO., SCHLACHTER A., POUMEYROL M., POPOFF MR. Apport de la technique d'amplification génique (PCR) au diagnostic des toxi-infections alimentaires à Clostridium perfringens. Med. Mal. Infect., 1993, 23, 70-7.

3 GKIOURTZIDIS K., FREY J., BOURTZI-HATZOPOULOU E., ILIADIS N., SARRIS K. PCR detection and prevalence of $\alpha \beta \beta 2 \varepsilon 1$ and enterotoxin genes in Clostridium perfringens isolated from lambs with clostridial dysentery. Vet. Microbiol., 2001, 82, 39-43.

4 HATHEWAY CL. Toxigenic clostridia. Clin. Microbiol. Rev., 1990, 3, 66-98.

5 HAVARD HL., HUNTER SEC., TITBALL RW. Comparison of the nucleotide sequence and development of a PCR test for the epsilon toxin gene of Clostridium perfringens type B and D. FEMS Microbiol. Lett., 1992, 97, 77-82.

6 JOHNSON S., GERDING DN. Enterotoxemic infections. In: ROOD JI., McCLANE B., SONGER JG., TITBALL RW. Eds. The clostridia: molecular biology and pathogenesis. London: Academic Press, 1997: 117-40.

7 KADRA B., GUILLOU JP., POPOFF M., BOURLIOUX P. Typing of sheep clinical isolates and identification of enterotoxigenic Clostridium perfringens strains by classical methods and by polymerase chain reaction (PCR). FEMS Immunol. Med. Microbiol., 1999, 24, 259-66.

8 KANAKARAJ R., HARRIS DL., SONGER JG., BOSWORTH B. Multiplex PCR assay for detection of Clostridium perfringens in feces and intestinal contents of pigs and swine feed. Vet. Microbiol., 1998, 63, 29-38.

9 KATAYAMA SL., MATSUSHITA O., MINAMI J., MIZOBUCHI S., OKABE A. Comparison of the alpha-toxin genes of Clostridium perfringens type $\mathrm{A}$ and $\mathrm{C}$ strains: evidence for extragenic regulation of transcription. Infect. Immun., 1993, 61, 457-63.

10 McDONEL JL. Toxins of Clostridium perfringens types A,B,C,D and E. In: DORNER F., DREWS J. Eds. Pharmacology of bacterial toxins. New York: Pergamon Press, 1986: 477-517. 
11 MEER R., SONGER G. Multiplex polimerase chain reaction assay for genotyping Clostridium perfringens. Am. J. Vet. Res., 1997, 58, 702-5.

12 NIILO L. Clostridium perfringens in animal disease: a review of current knowledge. Can. Vet. J., 1980, 21, 141-8.

13 OAKLEY CL., WARRACK GH. Routine typing of Clostridium welchii. J. Hyg. Camb., 1953, 51, 102-7.

14 OHSAKA A., TSUCHIYA M., OSHIO C., MIYAIRI M., SUZUKI K., YAMAKAWA Y. Aggregation of platelets in the mesenteric microcirculation of the rat induced by $\alpha$ toxin (phospholipase C) of Clostridium perfringens. Toxicon, 1978, 16, 333-41.

15 PETIT L., GILBERT M., POPOFF MR. Clostridium perfringens: toxinotype and genotype. Trends Microbiol., 1999, 7, 104-10.

16 SONGER JG. Clostridial enteric diseases of domestic animals. Clin. Microbiol. Rev., 1996, 9, 216-34.

17 SONGER JG., MEER RR. Genotyping of Clostridium perfringens by polymerase chain reaction is a useful adjunct to diagnosis of clostridial enteric disease in animals. Anaerobe, 1996, 2, 197-203.

18 STERNE M., BATTY I. Criteria for diagnosing clostridial infections in pathogenic clostridia. In: Pathogenic clostridia. London: Butterworth, 1975: 79-84

19 TITBALL RW., HUNTER SEC., MARTIN KL., MORRIS AD., SHUTTLEWORTH AD., RUBDIGE T., ANDERSON DW., KELLY DC. Molecular cloning and nucleotide sequence of the alpha-toxin (phospholipase C) of Clostridium perfringens. Infect. Immun., 1989, 57, 367-76.

20 YAMAGISHI T., SUGITANI K., TANISHIMA K., NAKAMURA S. Polymerase chain reaction test for differentiation of five types of Clostridium perfringens. Microbiol. Immunol., 1997, 41, 295-9. 